\title{
Determinants of CEO Power and Characteristics of Managerial Profile: Implications for Risk-Taking in Listed Tunisian Firms
}

\author{
Sana Ben Cheikh ${ }^{1,2}$ \\ ${ }^{1}$ ISG de Gabès, Université de Gabès, Tunisia \\ ${ }^{2}$ Labor of Finance, Gouvernance d'Entreprise, Finance Appliqué et Audit (GEF2A), ISG Tunis, Université de \\ Tunis, Tunisia \\ Correspondence: Sana Ben Cheikh, ISG Gabès, Rue Jilani Habib, 6002, Gabès; ISG Tunis, 41 Avenue de la \\ liberté, Cité Bouchoucha, Le Bardo, 2000 Tunis, Tunisia.
}

Received: February 17, 2014

Accepted: March 15, 2014

Online Published: May 25, 2014

doi:10.5539/ijef.v6n6p140

URL: http://dx.doi.org/10.5539/ijef.v6n6p140

\begin{abstract}
This paper identifies the impact of CEO power on risk-taking in listed firms and supports the strategic role of CEO from his personal profile. It specifies the managerial characteristics; demographic and professional aspects with reference to the upper echelons theory. The structural CEO power is measured by the combination of two titles held by the CEO and their seat in the board of directors. The empirical results reveal that the manager holding a structural power taking risky decisions. More explicitly, the CEO as the only internal in boards shows the highest risk regardless of his position or competence.
\end{abstract}

Keywords: CEO power, risk taking, managerial characteristics

\section{Introduction}

Today, rapid changes that characterize the current environment, market uncertainty and various economic crises raise the head of the importance of risk management and allowed companies to take the risk to develop. Each manager is sensitive to risk rather than another. In addition, the regulatory change creates risk that is in some cases favorable to the interests of the CEO as it can be favorable to the interests of the firm.

Several studies have supported the strategic role of the manager and his profile in firms. Previous studies of Jensen and Meckling (1976) focused on the human aspects of partners in firms or recent works of Malmendier, Tate and Yan (2005) who are interested in the profile and personal aspects that characterize the manager or studies of Brookman and Thistle (2009) who take into account the association between the managerial characteristics, the firm value and risk taking.

In this area, most studies focus only on the risk-taking but our study is different because it also takes into account the link between the CEO power and managerial characteristics.

Therefore, we choose to conduct our research on the Tunisian context for different considerations. First, the Tunisian legislature has provided several legal provisions regulating the privileged status of the Tunisian CEO. We cite, as such the creation of the Code of Commercial Companies in 2000. According to Article 217 of the Code, the manager is the chief executive who is responsible for the management of the firm. This same code reveals that the chief executive and the president of the firm are equipped with the same power.

Furthermore, studies on the Tunisian context are tried to make an association between risk-taking and the Tunisian governance system translates by the ownership structure and the board of directors (Belanes \& Hachana, 2010) or the power that the Tunisian CEO practice on the board of directors (Hachana \& Ben Cheikh, 2012) and the Tunisian CEO power who depends on the identity of controlling shareholders (Loukil \& Ben Cheikh, 2012).

Finally, the Tunisian context is characterized by small firms where the CEO marks a strategic effect on them. In addition, Tunisian firms still adopt the monistic structures where there is no separation between the functions of management.

Our theoretical contribution is to enrich the theoretical aspects of CEO in emerging countries and especially in Tunisia. Our contribution is more visible because previous studies were limited to treating the personal and professional aspects of the CEO in Anglo-Saxon, European and Asian context. Our contribution is also due to 
the lack of literature that deal with the relationship between risk taking and the CEO power since each of these aspects has been treated separately.

Our empirical contribution involves the construction of an index that measures the managerial power based on recent studies of Adams, Almeida and Ferreira (2009). Unlike these studies who are interested to measure the CEO power index, we are encouraged to use a sensitivity analysis that addresses the effect of each component of the CEO power index.

Empirically, we consider a sample of 39 Tunisian listed firms on the Tunisian Stock Exchange for period of 11 years from 2000 to 2010 . We try to measure the CEO power index composed by three dummy variables. Similarly, we refer to the explanatory variables reflecting the managerial characteristics. Finally, we measure their involvement and that of CEO power on risk of Tunisian firms.

This research is structured as follows: we present the theoretical foundations that deal with the CEO power, the managerial characteristics and their relationship with the degree of risk present in the firms. Then we discuss the empirical methodology adopted and the results obtained. And the last section concludes.

\section{Managerial Authority and Risk: Theorical Framework and Formulation of Assumptions}

On the one hand, we are interested to develop manifestations of managerial power. On the other hand, we explore the theoretical framework underlying the managerial characteristics. In both cases, we scrutinize the relationship with the degree of risk in firms.

\subsection{Managerial Power: Events and Implications}

The manager is a strategic partner in firms. His status is more important when he is more powerful. Liu and Jiraporn (2010) support this role and predict that the manager is seen as someone who makes strategic financing and investment decisions with profound implications on firm practices.

The dominance of the CEO is reflected by his degree of power. Brockmann, Hoffman, Dawley and Fornaciari (2004) state that there are two types of managerial power: a formal power that occurs when the CEO is also the Chairman of the Board of Directors, and informal power refers to prestige, social status and network maintained between the CEO and other partners.

The literature mentions various indicators reflecting managerial power. As such, Diga and Kelleher (2009) outline four manifestations of managerial power:

- A structural power equated with formal power or position power;

- A property power referred to the detention of firms' shares by manager;

- An expert power based on the network of relationships maintained with other partners;

- A prestige power associated with the profession exercised.

Furthermore, Bebchuk, Cohen and Ferrell (2009) show the dominance of manager on the results of the firm. They say that the authoritarian and powerful CEO is more discretionary and influence the strategic decisions of the firm. They also reveal that the personal qualities of managers are the image of innovation and development at the firm. The agency theory support the idea that managers are best positioned to manage the risks and are better informed than shareholders. In this case, the information has an influence on risky decisions made by managers.

We believe that the manager can acquire the power of three different but complementary ways:

- The managerial power is associated with tenure in the firm. CEO has a wealth of information on firm resources and a familiarity with its strategies. Therefore, the managerial power proliferates with a longer CEO tenure;

- The managerial power is also associated with being an active member or a chairman. This power may weaken the role of control assigned to the Board of Directors since the powerful manager can neutralize the role played by independent directors or influence decisions.

- Powerful CEO on the board will have the opportunity to influence the selection of members and develop personal relationships with them.

Thus, we adopt the following hypothesis:

$\mathrm{H} 1$ : the powerful CEO is more inclined to take more risk in decision making.

\subsection{Determinants of CEO Power}

Taking into account the approach taken by Adams et al. (2009), we use three indicators illustrating the intensity of CEO power. The first indicator is being Chairman of the Board, and the second is associated with being the 
founder of the firm and the third is associated with being the only inside director on the board.

In what follows we will analyze the different relationships that exist between the three manifestations of the CEO power and the degree of risk-taking by the manager.

On the theoretical side, the dual function is supported by the agency theory and the theory of resource dependence. According to these theories, the dual structure is characterized by a concentration of CEO power increasing opportunism and managerial discretion (Peng, Zhang and Li 2007). In this case, the manager will have sufficient influence on the board. Thus, the CEO may pursue risky investments since he is not controlled.

When he is the founder of the firm, he became risk averse. However, the stability of his position and family ties-building with members of the founding family encourages the extension of his investment horizons.

Nevertheless, this vision has changed according to some researchers, such as Xiao, Alhabeeb, Hong and Haynes (2001). They show that the CEO as owner and founder becomes more inclined to take risky decisions for the benefits of earnings that they generate. These also state that the owner and founder of the firm prefer the risk when making decisions. In this same sense, the founder behaves autocratic within the firm and takes individual decisions based on intuition.

However, the presence of inside directors on the board weakens the power and the CEO share ownership. To this end, they become competitors about the power and the position of CEO. According to the agency theory, a CEO who is an internal administrator handles more easily board.

\subsection{The Personal Characteristics and Managerial Decision Making Contributions to the Upper Echelons Theory}

Based on the upper echelons theory, Hambrick and Mason (1984) and Hambrick (2007) highlight the demographic and professional characteristics of managers holding leadership positions. In this context, they argue that the demographic characteristics of top managers reflect their strategic actions. These characteristics are tenure, age, experience, educational level and gender.

More specifically, the upper echelons theory has not extensively addressed gender diversity in top management; rather they prefer to analyze a homogeneous structure of leadership. The work of Krishnan and Park (2005) consider the manager man ablest to direct firm then women managers. This has been proved by Cheng, Chan and Leung (2010). This difference is attributed to the high risk aversion that characterizes the behavior of women managers.

According to Barker and Mueller (2002), managerial age is a necessary quality identifying the sociological aspect of the CEO. When managers are old, rigid and risk-averse do not easily accept new ideas. Proponents of the upper echelons theory add that older managers are more conservative unlike the young managers who are more open to new ideas and more involved in the development of new projects, but less prone to career stability.

Hambrick and Fukutomi (1991) and Finkelstein and Hambrick (1996) find that the tenured CEO is reluctant to make additional efforts and prefers to keep the process and procedure adopted. Several studies such as those of Barker and Mueller (2002) argue that as the age and tenure of CEO are developed, the less there will be an able to take risky decisions and innovative strategies.

In addition, the level of education is also a professional aspect. Wailderdsak and Suehiro (2004) show that the education level of the CEO reflects his capacity and considered as a measure of human capital. In addition, the level of education reflects the intellectual skills of the CEO. Thus, intellectual skills generate new managerial skills and realize competitive advantages for the firm. For Hitt and Tyler (1991), managers with a good education have more information for decision making.

According to the arguments of the upper echelons theory, we propose the following hypothesis:

H2: A CEO man, young, educated but inexperienced seeks to risk when making its decision.

\section{Empirical Methodology}

We present in this section the selected sample and the variables used.

\subsection{Sample and Data Collection}

We used a sample of 78 managers from 39 Tunisian listed firms for the period spanning 11 years between 2000 and 2010. The selected firms belong to the following sectors: food, service, industrial, communication, trade, leasing, banking, insurance, tourism and transport.

We must note that the information on the characteristics of Tunisian managers is not available and we have used an interview guide and a questionnaire. Our trips were made to the executive directors, if the opportunity is 
presented, except with the director of human resources.

Our sample includes 414 observations panel. Financial data are collected from Tunis Stock Exchange and the Financial Market Council (CMF). We used also the financial statements, annual reports and prospectuses of selected firms.

\subsection{Measurement of the Dependent Variable: The Risk}

Previous empirical studies of Smith and Stulz (1985) were considered among the first to model the determinants of risk management. More recently, empirical studies of Coles,_Daniel and Naveen (2006) and Chakraborty, Sheikh and Subramanian (2007) consider taking managerial risk closely linked to the overall risk of the firm. Most of these studies measured risk-taking by the volatility of returns (VOL).

VOL it: The volatility of the firm. It is defined as the standard deviation of daily returns recorded during the year with $\mathrm{Rd}_{\mathrm{J}}=\log$ Price $_{t}+$ Div - Log Price ${ }_{t-1}$. This variable is used by Brailsford, Oliver and Pua (2002). In empirical work, the control of the manager becomes more expensive with higher volatility of equity returns of the firms.

\subsection{Measurement of Independent Variables: The Managerial Authority and Personal Characteristics of CEO}

The study of Bach and Smith (2007) focus on the measures of managerial power that were previously identified by Finkelstein (1992). They empirically validated classification of dimensions of CEO power like the ownership, expertise, prestige and structural power.

Eisenhardt and Bourgeois (1988) characterize the powerful manager mainly on aspects of his structural power. It is a formal power that manager practice on the Board of Directors and other executives as a result of his hierarchical position in the firm. CEO holding structural power has a strong authority in decision making.

At this level, the CEO power comes from two resources. The first is the dual functions. The second is holding the title of founder of the firm.

Adams et al. (2005) add another variable to the side of the dual functions of direction and family founder. They approach the index by three variables. These three dummy variables are:

$\mathbf{i}_{1}$ no internal in the board : dummy variable equal to 1 if the $\mathrm{CEO}$ is the only inside director on the board and 0 otherwise.

$\mathbf{i}_{2}$ founder of the firm : dummy variable equal to 1 if the CEO is at the same time the founder of the firm and 0 otherwise.

$\mathbf{i}_{3}$ concentration position of Chairman and President of the firm : dummy variable equal to 1 if the CEO is also the Chairman and the president of the firm and 0 otherwise.

Regarding variables related to personal characteristics of managers, they are as follows:

TEN it: Tenure of CEO. This variable represents the number of years since the appointment of manager in the current position in the firm. The long length indicates the higher ability of the manager.

AGE it: Age of CEO. This variable reflects the knowledge and skills acquired by the manager in the firm since he was recruited. A young CEO agrees easier technological development and handles more easily new methods than an older CEO. These state that the older manager are more attached to the status quo and generate more prudent behavior. In this same sense, the older manager is more rigid to accept new ideas. Since the agency theory, the interests of managers and shareholders are aligned when the CEO reached the age of retirement. At this age, managers can no longer improve their personal wealth.

EDU it: Educational level of the CEO. This is a dummy variable equal to 1 if the CEO holds a master's degree or a license and 0 otherwise. Datta, Rajagoplan and Zhang. (2003) confirm that managers with good education oriented firms to new strategic directions. Gottesman and Morey (2006) state that the cognitive ability of the manager grows us the educational level is high.

GEN it: Gender of CEO. This is a dummy variable equal to 1 if the manager is a woman and 0 otherwise. Adams, Almeida and Ferreira (2009) show that women managers are represented as independent directors and applied the principles of governance in the firm. However, men are dominant and confident managers.

EXP it: Professional experience of the CEO. This variable represents the number of years since the CEO handles all operational positions throughout his career. The experience of the CEO is an important managerial characteristic and develops the cognitive orientation of the manager. 


\subsection{Measurement of Control Variables}

SIZ it: Size of the firm. This variable is measured by the natural logarithm of the book value of total assets: Ln assets. Guaj (1999) shows that there is a positive association between firm size and intentions of the CEO to take the risk. Similarly, Rogers (2002) confirms the same idea and uses the size of the firm as a measure of risk. For this reason, this relationship is reflected in the diversification. More explicitly, the large firms often have a capacity of diversification most notable that small firms.

DBT it: Debt. This variable is calculated by the ratio by the total debt of the firm to all shareholders' equity and liabilities. This variable is used to estimate the weight of debt in the total financing of the firm. Tufano (1996) shows that the higher the debt ratio, the higher the probability of failure and firms are likely to cover.

MTB it: Market to Book. This ratio is used to evaluate the financial performance of the firm. We can approximate the MTB by the ratio between the sum of market capitalization and total debt and book value of assets. According to Milgrom and Roberts (1992), the level of financial performance depends on the efforts of the managers on the firm profitability.

\section{Discussions and Analysis}

We present in this section the analysis of variables, the model estimation and the interpretation of results.

\subsection{Descriptive Analysis}

The descriptive analysis in Table 1 presented the mean, standard deviation, minimum and maximum variables of the study.

Table 1. Descriptive analysis of the variables

Panel A. CEO power index

\begin{tabular}{cccc}
\hline \multicolumn{2}{c}{ Variables } & Frequency & Percentage \\
\hline \multirow{2}{*}{$\mathbf{i}_{1}$} & 0 & 334 & $80.48 \%$ \\
& 1 & 81 & $19.52 \%$ \\
$\mathbf{i}_{2}$ & 0 & 348 & $83.86 \%$ \\
& 1 & 67 & $16.14 \%$ \\
$\mathbf{i}_{3}$ & 0 & 114 & $27.47 \%$ \\
& 1 & 301 & $72.53 \%$ \\
\hline
\end{tabular}

Note. Legend: $\mathbf{i}_{1}$ no internal in the board: dummy variable equal to 1 if the CEO is the only inside director on the board and 0 otherwise; $\mathbf{i}_{2}$ founder of the firm: dummy variable equal to 1 if the CEO is at the same time the founder of the firm and 0 otherwise; $\mathbf{i}_{3}$ concentration position of Chairman and President of the firm: dummy variable equal to 1 if the CEO is also the Chairman and the president of the firm and 0 otherwise.

Panel B. Characteristics of the CEO

\begin{tabular}{llllll}
\hline & TEN & AGE & EXP & SIZ & DEB \\
\hline $\mathbf{N}$ & 388 & 388 & 388 & 415 & 415 \\
Mean & 9.195876 & 52.71134 & 3.21381 & 15.72789 & 0.7007 \\
Standard deviation & 7.600339 & 8.358206 & 2.07698 & 2.652306 & 0.25912 \\
Minimum & 1 & 30 & 1 & 10.05073 & 0.052745 \\
Maximum & 36 & 78 & 8 & 21.12118 & 1.356006 \\
\hline
\end{tabular}

Note. Legend: TEN: CEO Tenure ; AGE: CEO Age ; EXP: CEO Experience; SIZ: Size of the firm; DEB: Debt of the firm.

Panel C. Binary variables

\begin{tabular}{cccc}
\hline & & N & Frequency \\
\hline \multirow{2}{*}{ GEN } & $\mathbf{0}$ & 376 & $96.91 \%$ \\
& $\mathbf{1}$ & 12 & $3.09 \%$ \\
EDU & $\mathbf{0}$ & 187 & $48.20 \%$ \\
& $\mathbf{1}$ & 201 & $51.80 \%$ \\
\hline
\end{tabular}

Note. Legend: GEN: CEO Gender; EDU: Education level of the CEO. 
Panel D. Risk of the firm

\begin{tabular}{lll}
\hline & VOL & MTB \\
\hline $\mathbf{N}$ & 415 & 414 \\
Mean & 0.187809 & 2.561162 \\
Standard deviation & 0.0226029 & 1.995618 \\
Minimum & 0 & 0 \\
Maximum & 0.222944 & 9.788 \\
\hline
\end{tabular}

Note. Legend: VOL: Volatility of the firm; MTB: Market to Book.

Panel A shows the frequency of binary variables comprising the index of managerial power. We note that $73 \%$ of Tunisian firms, there is a concentration of direction functions. While, the two other binary variables have a high frequency when they do not have any implication on the empowerment of the CEO.

From Panel B, we note that the Tunisian manager spends an average of nine years in the same firm and the average experience of the Tunisian managers is 3 years and limited to 8 years. In this sense, managers are usually nominated in other positions in other firms. This case is widely practiced in the state-controlled firms (Omri, 2003).

We also note that the Tunisian managers far beyond the retirement age (maximum 78 years). This trend can be explained by the fact that the majority of Tunisian firms are familial and CEO family, which promotes their managerial entrenchment. We note that the debt, considered as a control variable, reveals an average of $70 \%$. This allows estimating that more than half of listed Tunisian firms are indebted.

In Panel C, most observations indicate that Tunisian managers are men. We note that Tunisian firms in our sample do not support the gender diversification of the CEO. Rather they prefer the homogeneous structure of the managerial group. We note that half of the Tunisian managers from our sample are graduates.

From the Panel D, the average of volatility is about $18 \%$. We note that most Tunisian managers are risk averse this may be due to restrictions from the Code of Commercial Companies which may be related to certain control measures applied to the practices and decisions of the Tunisian manager.

The average of the MTB is around 2.561. This value is greater than 1, this means that the firms in our sample have an average book value less than the market value. This was recorded in several previous empirical studies.

\subsection{Analysis of Correlations}

We present in this part of the analysis Spearman correlation matrix shown in Table 2. We note that the CEO tenure is positively and significantly correlated to the CEO power index, on the one hand and the experience and age of the CEO, on the other hand. These correlations indicate that the expertise power strengthens when he is older in the firm. Therefore, as tenure is longer, the manager becomes older and more experienced.

At the same matrix, we note that the tenure of the manager is associated with volatility. This correlation shows that long-serving managers are less risk averse. However, volatility is negatively correlated with age and gender of the CEO. This explains why the woman CEO is more risk averse than men and the manager in advanced age no longer prefer to take risky decisions.

We note that the gender of CEO is negatively correlated with the CEO power and variables representing the managerial characteristics; the experience and level of education. This relationship confirms that the woman manager is not strongly present in the Tunisian firms. We reveal that Tunisian firms prefer leadership positions headed by men. These firms accept managers with an average level of education but rely more on those that are old and aged. 
Table 2. Spearman correlation matrix

\begin{tabular}{|c|c|c|c|c|c|c|c|c|c|c|}
\hline & ICP & TEN & EXP & AGE & EDU & GEN & МТВ & VOL & DEB & SIZ \\
\hline ICP & 1.000 & & & & & & & & & \\
\hline TEN & $0.3323 * *$ & 1.000 & & & & & & & & \\
\hline EXP & $0.2496^{* * *}$ & $0.2883^{* * *}$ & 1.000 & & & & & & & \\
\hline AGE & $0.2191 * *$ & $0.4595^{* *}$ & $0.1599 *$ & 1.000 & & & & & & \\
\hline EDU & -0.0968 & $0.1847 *$ & 0.0918 & -0.0324 & 1.000 & & & & & \\
\hline GEN & -0.0584 & $0.0079 *$ & -0.0278 & $0.0416^{*}$ & -0.0208 & 1.000 & & & & \\
\hline МТВ & -0.0484 & -0.0013 & -0.1427 & -0.0211 & -0.0511 & -0.0089 & 1.000 & & & \\
\hline VOL & 0.0114 & $0.0048^{* *}$ & 0.0366 & -0.0046 & $0.0955^{*}$ & $-0.0634^{*}$ & $0.0057^{* *}$ & 1.000 & & \\
\hline DEB & 0.0219 & -0.0078 & 0.0170 & 0.0141 & 0.0473 & -0.0089 & -0.0024 & -0.0209 & 1.000 & \\
\hline SIZ & -0.1910 & -0.0106 & $-0.0465 * *$ & 0.0193 & 0.1920 & -0.0778 & 0.0391 & 0.0938 & -0.0435 & 1.000 \\
\hline
\end{tabular}

Note. Legend: ICP: CEO power index; TEN: CEO Tenure; EXP: CEO Experience; AGE: CEO Age; EDU: Education level of CEO; GEN: CEO Gender; MTB: Market to Book; VOL: Volatility of the firm; DEB: Debt of the firm; SIZ: Size of the firm.

$*, * *, * *$ : statistically significant at the level of $10 \%, 5 \%$, and $1 \%$ respectively.

\subsection{Comparison of Average}

In this section, we examine the characteristics of the manager at different levels of the CEOs power ranging from 0 to 3. Therefore, we divide our sample into four groups. The first subgroup includes the Tunisian firms to which their managers do not hold a leadership position in the firm. The second subgroup encloses firms with managers holding a single leadership position. The third subgroup consists of firms with CEO holding at least 2 positions of leadership. The last subgroup is formed by firms with CEO holding a structural power due to the accumulation of management positions in the firm.

Subsequently, we try to check the average of the four groups. We then arrive at three links: (ICP = 0/1), (ICP = $0 / 2)$ and $(\mathrm{ICP}=0 / 3)$.

According to statistics obtained in Table 3, the three levels of power have not revealed significant differences in terms of explanatory variables for the three firms selected groups. We find that managers with high power (ICP = 3 ) are those the oldest and best experienced. However, managerial power increases as the managers become older. In other words, the expertise power of CEO of Tunisian firm's increases as the structural power strengthens.

The risk of the firm not strongly varies with different levels of CEO power. Thus, we affirm that the riskiest firms are those that are directed in the same way by an authoritarian manager than a CEO exercising structural power.

Firm performance is inversely correlated with different levels of managerial power.

Table 3. Comparison of average managerial characteristics depending on the CEO's power

\begin{tabular}{llll}
\hline & $\mathbf{I C P}=\mathbf{0} / \mathbf{I C P}=\mathbf{1}$ & $\mathbf{I C P}=\mathbf{0} / \mathbf{I C P}=\mathbf{2}$ & $\mathbf{I C P}=\mathbf{0} / \mathbf{I C P}=\mathbf{3}$ \\
\hline TEN & $-3.631^{*}$ & $-8.333^{* * *}$ & $-9.711^{* * *}$ \\
AGE & -2.286 & -7.062 & -5.288 \\
EXP & $-0.244^{*}$ & $-0.353^{* *}$ & $-0.416^{* * *}$ \\
EDU & $0.496^{* * *}$ & $-0.478^{* *}$ & $0.577^{* * *}$ \\
GEN & -0.046 & $0.026^{* * *}$ & 0.000 \\
MTB & $0.091^{* * *}$ & $0.098^{* *}$ & $1.306^{* * *}$ \\
VOL & $-0.0075^{* * *}$ & $-0.00659^{* * *}$ & $-0.00753^{* * *}$ \\
DEB & $-0.3096^{* *}$ & $0.1315^{* * *}$ & -0.20277 \\
SIZ & 1.7136 & 2.1793 & $2.9085^{* * *}$ \\
\hline
\end{tabular}

Note. Legend: ICP: CEO power index; TEN: CEO Tenure; EXP: CEO Experience; AGE: CEO Age; EDU: Education level of CEO; GEN: CEO Gender; MTB: Market to Book; VOL: Volatility of the firm; DEB: Debt of the firm; SIZ: Size of the firm.

$*, * *, * *$ : statistically significant at the level of $10 \%, 5 \%$, and $1 \%$ respectively. 


\subsection{Model and Estimation}

The regression model that we present below tests the impact of CEO power and the managerial characteristics on the risk of the firm.

$$
V O L_{i t}=\delta_{0}+\delta_{1} I C P_{i t}+\delta_{2} E D U_{i t}+\delta_{3} G E N_{i t}+\delta_{4} E X P_{i t}+\delta_{5} T E N_{i t}+\delta_{6} A G E_{i t}+\delta_{7} D E B_{i t}+\delta_{8} M T B_{i t}+\delta_{9} S I Z_{i t}+\varepsilon_{i t}
$$

The indices $\mathrm{i}$ and $\mathrm{t}$ correspond to the firm and the period of study. With residual term $\varepsilon$ it standard and $\partial$ it are the unknown parameters of the model.

Ensuring the presence of the individual effects due to the homogeneity test, we use panel data. In this case, we examine the models and check whether the observed individual effect is fixed or random. We then used the Hausman (1978) which discriminates between the fixed effect and random effect. According to our empirical results, the probability of the Hausman statistic is significant. Therefore, we reject the null hypothesis of no correlation between the individual effects and the explanatory variables and we adopt the fixed effect model.

Our estimates suffer from the problem of heteroscedasticity. We have corrected this problem by applying the test of Breusch-Pagen. While, we confirmed the absence of multicollinearity by calculating the VIF (Variance Inflation Factor) rated by $1 /\left(1-\mathrm{R}^{2}\right)$ and by estimating the correlation matrix of Pearson. We found that all values of the explanatory variables associated with VIF are less than 10 and we detected no correlation between the variables according to the correlation matrix.

We then refer to the GLS (Generalized Least Squares) regression method as used in the empirical analysis.

\subsection{Interpretation of Results}

The following table summarizes the results for the empirical model.

Table 4. Involvement of CEO power and managerial characteristics of the on the risk of the firm

\begin{tabular}{ll}
\hline & VOL \\
\hline ICP & $0.014^{* *}$ \\
TEN & $0.086^{*}$ \\
AGE & $-0.099^{*}$ \\
EDU & 0.796 \\
GEN & -0.166 \\
EXP & 0.833 \\
MTB & 0.856 \\
DEB & -0.158 \\
SIZ & $0.002^{* * *}$ \\
Constant & 0.233 \\
\hline
\end{tabular}

Note. Legend: ICP: CEO power index; TEN: CEO Tenure; EXP: CEO Experience; AGE: CEO Age; EDU: Education level of CEO; GEN: CEO Gender; MTB: Market to Book; VOL: Volatility of the firm; DEB: Debt of the firm; SIZ: Size of the firm.

$*, * *, * *$ : statistically significant at the level of $10 \%, 5 \%$, and $1 \%$ respectively.

Following our results, we reveal that the index CEO power act positively and significantly on the degree of risk in Tunisian firms. This link confirms our hypothesis H1. Thus, the structural power practiced by Tunisian managers is a legitimate and formal way and is strongly related to strategic decisions that have been taken with a considerable level of risk.

Education level shows no significant relationship with the risk measurement. This contradicts our hypothesis H2. The result shows that this test does not actually reflect the skills of Tunisian managers. Since the majority of our sample firms are family firms, the selection of managers is not done according to relationship with the founding family.

We also note that managers beyond the retirement age act negatively and significantly on the risk of Tunisian firms. As expected, older managers do not easily accept new ideas and new techniques remain inflexible. Our results agree with our hypothesis $\mathrm{H} 2$ which $\mathrm{CEO}$ advanced in age are more conservative and less willing to take the risk.

Contrary to this link, tenure has a positive and significant impact on volatility. Although the two managerial characteristics; age and tenure move in the same direction impact contradictory the risk-taking. We reveal that 
this relationship proves that the manager who works extensively in the firm becomes familiar with its structure, system and process. The tenure of Tunisian CEO reflects the expertise power. Therefore, powerful and tenured CEO has no constraint to take the risk when making its decision.

Our empirical results indicate that the experience of the manager does not explain the level of risk present in the Tunisian firms. According to our results, we reveal that the external manager is less experienced and does not have specific skills to the firm' sector. In addition, he creates problems of asymmetric information with the shareholder which indicates a high risk for the firm to underperform. Therefore, the external manager is not required to be able to take risk in their strategic decisions.

Managerial demographic characteristics expressed by the gender do not have a significant implication on the risk of the Tunisian firms. In this case, the relationship is explained by the idea that CEO man is considered the riskier manager. In this sense, the woman manager invests less in risky projects and appears more risk averse than man manager.

The relationship between size and risk of Tunisian firms is positive and significant. We note that large firms are characterized by the presence of agency problems and difficulties of centralization. While, manager in small firms becomes authoritarian, entrenched and takes risky decisions.

\subsection{Sensitivity Tests}

In this part of analysis, we will try to see if the different components of the CEO's power influence similarly the relationship between managerial characteristics and volatility of Tunisian firms by using the index of CEO power. For this reason, we introduce in the model three indicative variables of managerial power as follows.

$$
V O L_{i t}=\delta_{0}+\delta_{1} i_{i t}+\delta_{2} i_{i t}+\delta_{3} i_{3 i}+\delta_{4} E D U_{i t}+\delta_{5} G E N_{i t}+\delta_{6} E X P_{i t}+\delta_{7} T E N_{i t}+\delta_{8} D E B_{i t}+\delta_{9} M T B_{t}+\delta_{10} S I Z_{t t}+\varepsilon_{i t}
$$

We performed by detecting static problems (heteroscedasticity, multicollinearity and autocorrelation) in the same way as the previous empirical model. Finally, we use the method of Generalized Least Squares (GLS). The following table summarizes the results.

Table 5. Involvement of CEO power and managerial characteristics on the volatility of the firm

\begin{tabular}{ll}
\hline & VOL \\
\hline $\mathbf{i}_{1}$ & $0.072^{*}$ \\
$\mathbf{i}_{2}$ & -0.452 \\
$\mathbf{i}_{3}$ & -0.747 \\
TEN & -0.354 \\
AGE & 0.968 \\
EDU & $0.039^{* *}$ \\
GEN & $-0.001^{* * *}$ \\
EXP & 0.352 \\
MTB & $-0.832^{* *}$ \\
DEB & -0.445 \\
SIZ & $0.021 * *$ \\
Constant & -0.905 \\
\hline
\end{tabular}

Note. Legend: $\mathbf{i}_{1}$ no internal on the board: dummy variable equal to 1 if the CEO is the only inside director on the board and 0 otherwise; $\mathbf{i}_{2}$ founder of the firm: dummy variable equal to 1 if the CEO is at the same time the founder of the firm and 0 otherwise; $\mathbf{i}_{3}$ concentration position of Chairman and President of the firm: dummy variable equal to 1 if the $\mathrm{CEO}$ is also the Chairman and the president of the firm and 0 otherwise; TEN: CEO Tenure; AGE: CEO Age; GEN: CEO Gender; EDU: Education level of CEO; EXP: CEO Experience; DEB: Debt of the firm; MTB: Market to Book; SIZ: Size of the firm.

$*, * *, * *$ : statistically significant at the level of $10 \%, 5 \%$, and $1 \%$ respectively.

If we specify the effect of dummies variables of CEO power on to volatility, we note that the involvement of both variables (i2) and (i3) does not prove decisive. More explicitly, the results regarding the relationship between the presence of the $\mathrm{CEO}$ as the only internally in the board and the level of risk-taking measured by the volatility of returns corroborates to the agency theory. The presence of outside directors reveals their expertise in risk-taking. They may even encourage the manager to make a better selection of investment projects since manager creates a problem of asymmetry information due to the limited transfer of information between board 
members.

Our results also show that the level of risk of Tunisian firms cannot be explained by the dual functions of CEO. This relationship can be explained by the fact that with a high level of control over the managers, director's harsh complex objectives which stimulates risk-taking by managers to achieve and demonstrate their competence.

By using sensitivity analysis, we note that most of the variables that represent the characteristics of the CEO showed no change compared to their links with the previous study exception of tenure which becomes no explanatory variable of risk. We also note that the variable gender of CEO keeps a negative association with the risk, but becomes significant. This corroborates the idea that predicts the gender diversity of the CEO has no beneficial effect on risk.

\section{Conclusion}

The objective of this study is to identify the involvement of Tunisian CEO power and their personal and professional characteristics on risk-taking in listed firms in the Tunisian context. In this study, we addressed the specificity of the manager according to its characteristics. They are discerned by demographics, personal and professional. We explained the specificity of the manager according to the upper echelons theory by putting the existing relationships between the characteristics of the manager highlighted. In this study, we aimed also the relationship of power with the volatility of the firm. This approach is complementary to the first, for two reasons. On the one hand, the CEO power resulted in a set of characteristics that reflect the structural power. These factors are explained in three titles held by the CEO namely to be the Chairman, the founder or one of the founding members of the firm and the only inside director who sits on the board of directors. On the other hand, the CEO power is reflected in the tenure which reflects the power of expertise.

We have developed two empirical models as regressions applied to a sample of 39 Tunisian firms for a period of 11 years spanning between 2000 and 2010. The results of this empirical analysis show that the most powerful Tunisian CEO is one who takes the risky decisions. It is neither his competition nor his hierarchical position that promotes power is rather tenure which guarantees its expertise in power Tunisian firms. Following the approach taken by Adams et al. (2009) to formulate the index of CEO power, we unveiled being the only internal to the board reveals more risk in Tunisian firms. Thus, the presence of other external directors as with better expertise in risk-taking is most notable in Tunisian firms and therefore they are best positioned to guide the manager to choose the right project.

This study can be enriched by taking into account certain other measures of risk that are related to either the investment and financial policy and not only to the overall risk. In addition, an analysis by activity sector is interesting to compare the profiles of Tunisian managers across sectors activity of firms to which they belong.

\section{References}

Adams, R. B., Almeida, H., \& Ferreira, D. (2005). Powerful CEOs and their associations with corporate performance. Strategic Management Journal, 12, 135-153.

Adams, R. B., Almeida, H., \& Ferreira, D. (2009). Understanding the relationship between founder-CEOs and firm performance. Journal of Empirical Finance, 16(1), 136-150. http://dx.doi.org/10.1016/j.jempfin.2008.05.002

Bach, S. B., \& Smith, A. D. (2007). Are powerful CEOs beneficial to post-IPO survival in high technology industries? An empirical investigation. The Journal of High Technology Management Research, 18(1), $31-$ 42. http://dx.doi.org/10.1016/j.hitech.2007.03.002

Barker, V. L., \& Mueller, G. C. (2002). CEO Characteristics and Firm R\&D Spending. Management Science, 48(6), 782-801. http://dx.doi.org/10.1287/mnsc.48.6.782.187

Bebchuk, L., Cohen, A., \& Ferrell, A. (2009). What matters in corporate governance? Review of Financial Studies, 23(3), 949-961. http://dx.doi.org/10.2139/ssrn.593423

Belanes, A., \& Hachana, R. (2010). Biais cognitifs et prise de risque managérial: validation empirique dans le contexte tunisien. Management International, 14(2), 105-119. http://dx.doi.org/10.7202/039551ar

Ben Cheikh, S., \& Loukil, N. (2012). Tunisian CEO power and controlling shareholder identity: Principal-principal perspective. International Journal of Corporate Governance, 3(2/3/4), 163-181. http://dx.doi.org/10.1504/IJCG.2012.051860

Brailsford, T. J., Oliver, B. R., \& Pua, S. L. H. (2002). On the relation between ownership structure and capital 
structure. Journal of Accounting and Finance, 42, 1-26. http://dx.doi.org/10.1111/1467-629X.00001

Brockmann, E. N., Hoffman, J. J., Dawley, D. D., \& Fornaciari, C. J. (2004). The impact of CEO duality and prestige on a bankrupt organization. Journal of Management Issues, 16(2), 178-196.

Brookman, J., \& Thistle, P. D. (2009). CEO tenure, the risk of termination and firm value. Journal of Corporate Finance, 15(3), 331-344. http://dx.doi.org/10.1016/j.jcorpfin.2009.01.002

Chakraborty, A., Sheikh, S., \& Subramanian, N. (2007). Termination risk and managerial risk taking. Journal of Corporate Finance, 13,170-188. http://dx.doi.org/10.1016/j.jcorpfin.2006.04.001

Cheng, L. T. W., Chan, R. Y. K., \& Leung, T. Y. (2010). Management demography and corporate performance: Evidence from China. International Business Review, 19(3), 261-275. http://dx.doi.org/10.1016/j.ibusrev.2009.12.007

Coles, J. L., Daniel, N. D., \& Naveen, L. (2006). Managerial incentives and risk taking. Journal of Financial Economics, 79, 431-468. http://dx.doi.org/10.1016/j.jfineco.2004.09.004

Datta, D. K., Rajagoplan, N., \& Zhang, Y. (2003). New CEO openness to change and strategic persistence to moderating role of industry characteristics. Journal of Management, 14(2), 101-114.

Diga, M., \& Kelleher, T. (2009). Social media use, perceptions of decisions-making power and public relations roles. Public Relations Review, 35, 440-442. http://dx.doi.org/10.1016/j.pubrev.2009.07.003

Eisenhardt, K., \& Bourgeois, L. (1988). Politics of strategic decision-making in high velocity environments: Toward a Mid-Range Theory. Academy of Management Journal, 31, 737-770. http://dx.doi.org/10.2307/256337

Finkelstein, S. (1992). Power in top management teams: Dimensions, measurement and validation. Academy of Management Journal, 35, 505-538. http://dx.doi.org/10.2307/256485

Gottesman, A., \& Morey, M. (2006). Manager education and mutual fund performance. Journal of Empirical Finance, 13, 145-182. http://dx.doi.org/10.1016/j.jempfin.2005.10.001

Hachana, R., \& Ben Cheikh, S. (2012). Understanding the relationship between governance mechanisms firm performance and CEO power within Tunisian context. International Journal of Business and Emerging Markets, 4(3), 241-257. http://dx.doi.org/10.1504/IJBEM.2012.047790

Hambrick, D. C. (2007). Upper echelons: An update. Academy of Management Review, 32, 334-343. http://dx.doi.org/10.5465/AMR.2007.24345254

Hambrick, D. C., \& Fukutomi, G. D. (1991). The seasons of CEOs tenure. Academy of Management Review, 16, 719-742. http://dx.doi.org/10.2307/258978

Hambrick, D. C., \& Mason, P. A. (1984). Upper echelons: The organization as a reflection of its top management. Academy of Management Journal, 193-206. http://dx.doi.org/10.2307/258434

Hitt, M. A., \& Tyler, B. B. (1991). Strategic decision models: Integrating different perspectives. Strategic Management Journal, 12, 327-351. http://dx.doi.org/10.1002/smj.4250120502

Jensen, M., \& Meckling, W. H. (1976). Theory of a firm: Managerial behaviour, agency costs and ownership structure. Journal of Financial Economics, 3, 305-360. http://dx.doi.org/10.1016/0304-405X(76)90026-X

Krishnan, H. A., \& Park, D. (2005). A few good women: On top management teams. Journal of Business Research, 58(12), 1712-1720. http://dx.doi.org/10.1016/j.jbusres.2004.09.003

Liu, Y., \& Jirapon, P. (2010). The effect of CEO power on board ratings and yields. Journal of Empirical Finance, 17, 744-762. http://dx.doi.org/10.1016/j.jempfin.2010.03.003

Malmendier, U., Tate, G., \& Yan, J. (2005). Corporate financial policies with overconfident mangers. Journal of Finance, 60(6), 2661-2700. http://dx.doi.org/10.1111/j.1540-6261.2005.00813.x

Milgrom, P., \& Roberts, M. (1992). Economics, Organization and Management. New Jersey: Prentice-Hall International, Englewood Cliffs.

Omri, A. (2003). Système de gouvernance et performance des entreprises tunisiennes. Revue Française de Gestion, 1(142), 85-100. http://dx.doi.org/10.3166/rfg.142.85-102

Peng, M. W., Zhang, S., \& Li, X. (2007). Duality and firm performance during China's institutional transitions. Managerial and Organization Review, 3(2), 205-225. http://dx.doi.org/10.1111/j.1740-8784.2007.00069.x

Smith, C., \& Stulz, R. (1985). The determinants of firms' hedging policies. Journal of Financial and 
Quantitative Analysis, 20(4), 391-406. http://dx.doi.org/10.2307/2330757

Tufano, P. (1996). Who managers risk? An empirical examination of risk management practices in the gold mining industry. The Journal of Finance, 51(4), 1097-1100. http://dx.doi.org/10.1111/j.1540-6261.1996.tb04064.x

Wailderdsak, N., \& Suehiro, A. (2004). Top executive origins: Comparative study between Japan and Thailand. Asian Business and Management, 3, 85-104. http://dx.doi.org/10.1057/palgrave.abm.9200071

Xiao, J., Alhabeeb, M., Hong, G. S., \& Haynes, G. (2001). Attitude toward risk and risk taking behavior of business-owning families. The Journal of Consumer Affairs, 35(2), 226-306. http://dx.doi.org/10.1111/j.1745-6606.2001.tb00116.x

\section{Copyrights}

Copyright for this article is retained by the author(s), with first publication rights granted to the journal.

This is an open-access article distributed under the terms and conditions of the Creative Commons Attribution license (http://creativecommons.org/licenses/by/3.0/). 